\title{
Effects of Olive (Olea europaea L.) Leaves with Antioxidant and Antimicrobial Activities on In Vitro Ruminal Fermentation and Methane Emission
}

\author{
Shin Ja Lee ${ }^{1,+(\mathbb{D})}$, Hyun Sang Kim ${ }^{2,+}\left(\mathbb{D}\right.$, Jun Sik Eom ${ }^{2}$, You Young Choi ${ }^{2}$, Seong Uk Jo ${ }^{2}$, Gyo Moon Chu ${ }^{3}$, \\ Yookyung Lee ${ }^{4}$, Jakyeom Seo ${ }^{5}$, Kyoung Hoon Kim ${ }^{6,7}$ and Sung Sill Lee ${ }^{1,2, * \mathbb{D}}$
}

check for

updates

Citation: Lee, S.J.; Kim, H.S.; Eom, J.S.; Choi, Y.Y.; Jo, S.U.; Chu, G.M.; Lee, Y.; Seo, J.; Kim, K.H.; Lee, S.S. Effects of Olive (Olea europaea L.) Leaves with Antioxidant and Antimicrobial Activities on In Vitro Ruminal Fermentation and Methane Emission. Animals 2021, 11, 2008. https://doi.org/10.3390/ani11072008

Academic Editor: Mirja Wilkens

Received: 12 May 2021

Accepted: 1 July 2021

Published: 5 July 2021

Publisher's Note: MDPI stays neutral with regard to jurisdictional claims in published maps and institutional affiliations.

Copyright: (C) 2021 by the authors. Licensee MDPI, Basel, Switzerland. This article is an open access article distributed under the terms and conditions of the Creative Commons Attribution (CC BY) license (https:// creativecommons.org/licenses/by/ $4.0 /)$.
1 Institute of Agriculture and Life Science \& University-Centered Labs, Gyeongsang National University, Jinju-si 52828, Gyeongsangnam-do, Korea; tlswk1000@hanmail.net

2 Division of Applied Life Science (BK21), Gyeongsang National University, Jinju-si 52828, Gyeongsangnam-do, Korea; 2437401@naver.com (H.S.K.); skyandstar07@naver.com (J.S.E.); dudolboy301@naver.com (Y.Y.C.); jsu9412@naver.com (S.U.J.)

3 Nonghyupfeed INC. 337, Uam-ro, Nam-gu, Busan 48475, Korea; gyomoon96@hanmail.net

4 Animal Nutrition and Physiology Team, National Institute of Animal Science, RDA, Jeonju-si 55365, Jeonrabuk-do, Korea; yoo3930@korea.kr

5 Department of Animal Science, Life and Industry Convergence Research Institute, Pusan National University, Miryang 50463, Korea; jseo81@pusan.ac.kr

6 Department of International Agricultural Technology, Graduate School of International Agricultural Technology, Seoul National University, Pyeongchang 25354, Gangwon-do, Korea; khhkim@snu.ac.kr

7 Department of Ecofriendly Livestock Science, Institute of Green Bio Science and Technology, Seoul National University, Pyeongchang 25354, Gangwon-do, Korea

* Correspondence: 1ss@gnu.ac.kr; Tel.: +82-055-772-1883; Fax: +82-055-772-1889

+ These authors contributed equally to this work.

Simple Summary: Olives are cultivated mostly in the Mediterranean as well as in Asia Minor, Korea, Japan, and China. Olive oil is currently used as a food ingredient in human diet, and its consumption is gradually expanding in various countries. Therefore, olive cultivation and oil extraction produce a significant amount of byproducts; providing these byproducts as feed to livestock has been attempted for a long period. Economic, environmental, and nutritional considerations make the use of olive byproducts efficient and cost-effective as feed for ruminants. Among the olive byproducts, olive leaves (OLs) contain higher levels of polyphenols than olive fruits, and have a very high feed value. In this study, it was confirmed that methane production decreased during $12 \mathrm{~h}$ of in vitro fermentation, and the number of fat-utilizing microorganisms increased in the 5\% OLs group. OLs were found to show antioxidant and antimicrobial activity. Moreover, the proportion of cellulose-degrading bacteria, Fibrobacter succinogenes, Ruminococcus albus, and Ruminococcus flavefaciens increased in the 5\% OLs group at $12 \mathrm{~h}$ and decreased at $24 \mathrm{~h}$. Olive leaves are believed to be very useful as feed additives and supplements for ruminants.

Abstract: We evaluated whether olive leaves (OLs) are effective as feed additives and supplements for ruminants and the potential methane reduction effects during in vitro fermentation. Two Hanwoo cows ( $460 \pm 20 \mathrm{~kg}$ ) equipped with cannula were fed Timothy hay and corn-based feed $3 \%$ of the body weight at a ratio of 6:4 (8:30 a.m. and 5:00 p.m.). Ruminal fluid from the cows was collected and mixed before morning feeding. In vitro batch fermentation was monitored after 12 and $24 \mathrm{~h}$ of incubation at $39{ }^{\circ} \mathrm{C}$, and OLs were used as supplements to achieve the concentration of $5 \%$ in the basal diet. At $12 \mathrm{~h}$ of fermentation, methane production decreased in the $5 \%$ OLs group compared to that in the control group, but not at $24 \mathrm{~h}$. The proportion of cellulose-degrading bacteria, Fibrobacter succinogenes, Ruminococcus albus, and Ruminococcus flavefaciens, tended to increase in the $5 \%$ OLs group at $12 \mathrm{~h}$. The amount of ammonia produced was the same as the polymerase chain reaction result for Prevotella ruminicola. At $12 \mathrm{~h}$, the proportion of Prevotella ruminicola was significantly higher in the 5\% OLs group. OLs may be used incorporated with protein byproducts or other methane-reducing agents in animal feed. 
Keywords: olive leaves; antioxidant; antimicrobial agent; ruminal fermentation; methane production; animal feed

\section{Introduction}

Olive leaves (OLs) are a byproduct of olive production and processing, accounting for up to $10 \%$ of the weight in olive production; their high polyphenol content $(1 \%-14 \%)$ makes them an inexpensive source of antioxidant compounds [1,2]. They have been found to contain a large amount of high value-added antioxidants (oleuropein, hydroxytyrosol, carotene, triglycerides, tocopherol, and sitosterol) with antibacterial properties. Olive leaves (OLs) are used as feed additives and in medicine [3-5]. In particular, OLs are found to be effective in treating hypoglycemia and hypocholesterolemia due to their high antibacterial, antioxidant, and anti-inflammatory effects [6,7]. The antioxidant activity of OLs extracts (OLE) is mainly due to phenolic components including luteolin and hydroxytyrosol, as well as oleuropein, the main component in OLE, which have powerful anti-inflammatory, antibacterial, and antioxidant properties [8-11].

Olive leaves (OLs) have been used as animal feed due to their beneficial properties. Molina-Alcaide et al. [12] fed sheep and goats with olive tree byproducts and olive oil extract and studied the effects of OLs on digestion, decomposition, ruminal fermentation, animal performance, and product quality; they reported OLs to exert sufficient potential as feed for ruminants [12]. The most important greenhouse gas released from ruminal fermentation is methane $\left(\mathrm{CH}_{4}\right)$. In the study of Shakeri et al. [13], OLs and chloroform OLE reduced $\mathrm{CH}_{4}$ production by reducing ammonia $\left(\mathrm{NH}_{3}\right)$ production and increasing propionate level in the rumen, suggesting that they could help reduce $\mathrm{CH}_{4}$ production when supplemented in feed. The fatty acid composition in OLs byproducts is a particularly important factor. In addition, OLs are characterized by low digestibility and low crude protein $(\mathrm{CP})$ content [14]. However, if properly supplemented, it can be successfully used in animal feed [15].

The use of olive cakes in ruminant feeds results in different rates of ruminant fermentation and digestibility depending on the method of administration and the proportion in the diet [16]. Based on the results of evaluation of apparent digestibility and digestibility in the intestine, olive cakes can be used in silage or feed blocks [12].

Extracted olive cakes provide cheap energy and fiber to animals, and high-fat olive cakes can be used to improve the fat quality of animal products [12]. Olive leaves (OLs) represent a valuable material for developing functional animal feed. In this study, we determined whether antioxidant-rich OLs have potential as $\mathrm{CH}_{4}$ reducing feed additives.

\section{Materials and Methods}

\subsection{Sample Preparation}

Olive leaves (OLs) were obtained from Spain (Teetraum, Wollenhaupt Co., Ltd., Reinbek, Germany), and were purchased from CJ ENM Co., Ltd. (Seocho-gu, Seoul, Korea). Olive leaves (OLs) were dried for $2 \mathrm{~h}$ in a dry oven (TEIOTECH, Daejeon, Korea) at $55^{\circ} \mathrm{C}$ and crushed with a $2 \mathrm{~mm}$ screen using a Wiley mill (Model 4; Thomas Scientific, Swedesboro, NJ, USA). Analysis of the general components of OLs was performed according to the AOAC method [17]; the following components were analyzed: dry matter (DM; method 934.01), CP (method 954.01), crude fiber (CF; method 962.09), ether extract (EE; method 920.39), and crude ash (CA; method 942.05). Neutral detergent fibers (NDF) were analyzed using heat-resistant amylase, and acid detergent fibers (ADF), including residual ash, were analyzed using the method of Van Soest, Robertson, and Lewis [18].

\subsection{In Vitro Batch Fermentation}

Two rumen-fistulated, non-lactating Hanwoo cows of body weight $460 \pm 20 \mathrm{~kg}$ were used as ruminal inoculum donors. They were fed a basal diet of $60 \%$ Timothy hay and 
$40 \%$ corn-based feed (CP, $120 \mathrm{~g} / \mathrm{kg}$; EE, $15 \mathrm{~g} / \mathrm{kg}$; CF, $150 \mathrm{~g} / \mathrm{kg}$; CA, $120 \mathrm{~g} / \mathrm{kg}$; Ca, $7.5 \mathrm{~g} / \mathrm{kg}$; $\mathrm{P}, 9.0 \mathrm{~g} / \mathrm{kg} ; 690 \mathrm{~g} / \mathrm{kg}$ DM basis) at the energy maintenance level (3\% DM of their BW). The cows had free access to clean drinking water and a mineral block. Feed was offered at 8:30 a.m. and 5:00 p.m. Ruminal fluid was collected and mixed before morning feeding from two Hanwoo cows. After passing through it using 4 layers of cheese cloth, it was placed in an insulated bottle maintained at $39^{\circ} \mathrm{C}$ and moved to the laboratory in a vacuum state [19]. Rumen fluid was mixed with McDougall's buffer [20] artificial saliva in a ratio of 1:2 (V:V). A $15 \mathrm{~mL}$ mixing buffer was added to a $50 \mathrm{~mL}$ serum bottle, and $300 \mathrm{mg}$ (based on DM) of Timothy as a substrate was prepared (control: without OLs, $0 \% ; 5 \%$ OLs group: supplementation $5 \%$ of OLs at the rate of Timothy hay). All experiments were conducted by dispensing carbon dioxide $\left(\mathrm{CO}_{2}\right)$ gas to maintain anaerobicity, and the serum bottle was sealed with a butyl rubber stopper and an aluminum cap to maintain anaerobicity. The experimental design was completely randomized and was run in triplicate $(n=3)$. Gas production was monitored after 12 and $24 \mathrm{~h}$ of incubation at $39^{\circ} \mathrm{C}$.

\subsection{Total Polyphenols, Total Flavonoid Contents, and Antioxidant Activity}

Total phenol content was analyzed by the method of Singleton and Rossi [21]. The analytical procedure was to react $0.5 \mathrm{~mL}$ of diluted sample with $2.5 \mathrm{~mL}$ of $0.2 \mathrm{M} / \mathrm{L}$ FolinCiocalteu reagent for $4 \mathrm{~min}$, and $2 \mathrm{~mL}$ of saturated sodium carbonate solution $(75 \mathrm{~g} / \mathrm{L})$ was added to the reaction mixture. After incubation at room temperature for $2 \mathrm{~h}$, absorbance measurements were measured at $760 \mathrm{~nm}$. Gallic acid (GAE) was used as a reference standard calibration curve and the results were expressed as milligram gallic acid equivalent (mg GAE)/g dry weight (g DW).

Total flavonoids were used by modifying the method of Meda et al. [22]. A sample $(0.25 \mathrm{~mL})$ was placed in a tube containing $1 \mathrm{~mL}$ of double-distilled water, $5 \% \mathrm{NaNO}_{2}$ was added, and after $5 \mathrm{~min}, 0.075 \mathrm{~mL}$ of $10 \% \mathrm{AlCl}_{3}$ was added to react, and $0.5 \mathrm{~mL}$ of $1 \mathrm{M}$ $\mathrm{NaOH}$ was added after $1 \mathrm{~min}$. The volume of the reaction solution was adjusted to $2.5 \mathrm{~mL}$ with double-distilled water. The absorbance of the solution at a wavelength of $410 \mathrm{~nm}$ was measured using a spectrophotometer (Ultrospec 2100 pro, Amersham Pharmacia Biotech Co., Piscataway, NJ, USA). Quercetin was used as a standard calibration curve to quantify total flavonoid content. Results were expressed as milligram quercetin equivalents (mg $\mathrm{QE}) / \mathrm{g}$ dry weight (g DW).

Sample treatment for analyzing 2,2-diphenyl-1-picrylhydrazyl (DPPH) radical scavenging activity $(0.05-1 \mathrm{mg} / \mathrm{mL}$ in DMSO) was used by modifying the method of BrandWilliams et al. [23] to suit the experimental purpose. The standard material for radical scavenging activity was used as L-ascorbic acid. The radical scavenging activity of the sample was calculated and expressed by the IC50 value.

2,2'-Azino-bis(3-ethylbenzothiazoline-6-sulfonic acid (ABTS) radical scavenging activity was determined using the method reported by Re et al. [24]. 2,2'-Azino-bis(3ethylbenzothiazoline-6-sulfonic acid $(7 \mathrm{mM})$ and potassium sulfate $(2.45 \mathrm{mM})$ were reacted at room temperature for $12 \mathrm{~h}$ to form an ABTS radical cation (ABTS +). The ABTS + solution was measured by absorbance at $734 \mathrm{~nm}$. The radical scavenging activity of the tested samples was calculated and expressed as the IC50 value.

The hydroxyl $(\mathrm{HO})$ radical scavenging activity of OLE at various concentrations was determined by Elizabeth et al. [25]. The absorbance of the mixture was measured at $532 \mathrm{~nm}$. Standard substances of $\mathrm{HO}$ radical scavenging activity were compared and analyzed using butylated hydroxyanisole (BHA) and catechin.

Nitric oxide (NO) radical scavenging ability was measured by modifying the Lee [26] method. The modified content was analyzed by the Griess-Ilosvay reaction. Butylated hydroxyanisole (BHA) was used as the standard, and absorbance was measured at $546 \mathrm{~nm}$.

\subsection{Assessment of Antimicrobial Assay}

Antibacterial analysis was performed using a standard disc diffusion method using Escherichia coli, Pseudomonas aeruginosa, Klebsiella pneumoniae, and Staphylococcus aureus. 
McFarland standard culture conditions were used after incubation at $37{ }^{\circ} \mathrm{C}$ for $24 \mathrm{~h}$. Saturated cultures were taken, inoculated on Mueller Hinton agar plates, and bacteria were cultured to determine the vitality of antibacterial assays. For OLE, $50 \mu \mathrm{L}$ of each plate was placed on a sterile paper disc with a diameter of $5 \mathrm{~mm}$, incubated at $37^{\circ} \mathrm{C}$ for $24 \mathrm{~h}$, and the surrounding clear zone was checked to measure the antimicrobial activity based on the inhibitory area $[27,28]$.

As for the criteria for determining the clear zone, when the medium was visually checked at a distance of about $30 \mathrm{~cm}$, the range in which bacteria did not grow at all was recognized as the clear zone. If the clear zone was elliptical, the smaller diameter was recognized as the clear zone. The areas where the bacteria grew lightly or had single colonies were excluded from the clear zone [28].

\subsection{Analysis of Metabolites in Gas Chromatography-Mass Spectrometry (GC-MS)}

Gas chromatography-mass spectrometry (GC-MS) was used to analyze carbohydrate metabolites in OLE. For the analysis, an RTx-5MS capillary column $(30 \mathrm{~m} \times 0.25 \mathrm{~mm}$, id $\times 0.25 \mu \mathrm{m}$ film thickness, Restek Co., Bellefonte, PA, USA) was used. As for the analysis conditions, helium gas was used as a transport gas at a flow rate of $0.95 \mathrm{~mL} / \mathrm{min}$, and the initial $2 \mathrm{~min}$ was increased from $70{ }^{\circ} \mathrm{C}$ to $300{ }^{\circ} \mathrm{C}$ at a rate of $20^{\circ} \mathrm{C} / \mathrm{min}$. It was kept in this state for $3 \mathrm{~min}$. The transfer line temperature was $280{ }^{\circ} \mathrm{C}$ and the ion source temperature was $230{ }^{\circ} \mathrm{C}$. The scans event time source was $0.003 \mathrm{~s}, 15 \mathrm{eV}$ scan. MS data ranged from $\mathrm{m} / \mathrm{z}$ $45 \sim 550$ [29].

\subsection{Analysis of In Vitro Fermentation}

The supernatant of the culture medium was sampled to analyze $\mathrm{pH}$, volatile fatty acid (VFAs), and microbial growth rate (MRG). The $\mathrm{pH}$ was measured using a pH meter (MP230, Mettler-Toledo, Greifensee, Switzerland). To analyze VFAs (total VFA, acetate, propionate, and butyrate), the supernatant of the culture medium was centrifuged at $10,483 \times g$ for $3 \mathrm{~min}$, and the supernatant was collected and used for analysis. The content of VFAs was measured by high-performance liquid chromatography (L-2200; Hitachi, Tokyo, Japan). Their content was individually calculated using the standard curve equation, and the value of ppm was converted to $\mathrm{mmol} / \mathrm{L}$. Microbial growth rate (MRG) was determined by centrifuging the supernatant at $655 \times g$ for $3 \mathrm{~min}$, then centrifuging once more at $14,269 \times g$, washing 4 times with sodium phosphate buffer and then using a spectrophotometer (Model 680, Bio-Rad Laboratories, Hercules, CA, USA) to analyze the OD (optical density) value at $550 \mathrm{~nm}$.

Total gas production was measured using a digital readout voltmeter (Laurel Electronics, Inc., Costa Mesa, CA, USA) in the headspace above the culture bottle during each fermentation time. The pressure of the gas was recorded on the LED display after the hypodermic needle was inserted into the culture bottle. Gas samples for $\mathrm{CH}_{4}$ and $\mathrm{CO}_{2}$ analysis were transferred to vacuum test tubes (Vacutainer, Becton Dickinson, Franklin Lakes, NJ, USA) and analyzed using a column TCD detector (HP 5890; Agilent Technologies, Santa Clara, CA, USA). Carboxen 1006PLOT capillary column $30 \mathrm{~m} \times 0.53 \mathrm{~mm}$ (Supelco) thermal conductivity detector was used [30].

\subsection{Total DNA Extraction and Quantitative Real-Time Polymerase Chain Reaction}

Total DNA was extracted from the pellet stored at $-80^{\circ} \mathrm{C}$ using the repeated bead beating in the subsequent DNA purification by QIA ${ }^{\circledR}$ columns (referred to as repeated bead beating plus column (RBB $+\mathrm{C}$ ) method) [31]. Genomic DNA was treated with RNase $A$ and proteinase $\mathrm{K}$ and purified using columns from the DokDo-Prep Genomic DNA Kit (Elpis-Biotech, Daejeon, Korea). The concentration and purity of total DNA were measured using a NanoDrop (ND-1000, Thermo Fisher, Waltham, MA, USA). Quantitative real-time polymerase chain reaction (PCR) assays were performed on a CFX 96 Touch system (BioRad Laboratories, Inc., Hercules, CA, USA). Quantitative real-time PCR was carried out according to the manufacturer's instructions, as follows. 
The initiation for one cycle at $95{ }^{\circ} \mathrm{C}$ for $10 \mathrm{~min}, 40$ cycles each for denaturation at $95{ }^{\circ} \mathrm{C}$ for $30 \mathrm{~s}$, annealing at $60{ }^{\circ} \mathrm{C}$ for $30 \mathrm{~s}$, and elongation at $72{ }^{\circ} \mathrm{C}$ for $30 \mathrm{~s}$, and final elongation at $72{ }^{\circ} \mathrm{C}$ for $5 \mathrm{~min}$.

Fluorescence was recorded at the end of each denaturation and extension step, and the specificity of the sample was confirmed via dissociation curve analysis of PCR end products by increasing the temperature at a rate of $1^{\circ} \mathrm{C}$ every $30 \mathrm{~s}$, from $60{ }^{\circ} \mathrm{C}$ to $95^{\circ} \mathrm{C}$.

The PCR primers include general bacteria [32], ciliated protozoa [33], fungi [32], methanogenic archaea [33], Fibrobacter succinogenes (F. succinogenes) [32], Ruminococcus albus (R. albus) [34], Ruminococcus flavefaciens (R. flavefaciens) [32], Prevotella ruminicola (P. ruminicola) [33], Butyrivibrio fibrisolvens (B. fibrisolvens) [35], Butyrivibrio proteoclasticus (B. proteoclasticus) [36], and Anearovibrio lipolytica (A. lipolytica) [37] (Table 1).

Table 1. Polymerase chain reaction primer for quantitative real-time polymerase chain reaction assays.

\begin{tabular}{|c|c|c|c|c|}
\hline Target Species & Primer & Sequence $\left(5^{\prime} \rightarrow 3^{\prime}\right)$ & Size (bp) & Reference \\
\hline \multirow{2}{*}{ General bacteria } & $\mathrm{F}$ & CGGCAACGAGCGCAACCC & \multirow{2}{*}{130} & \multirow{2}{*}[32]{} \\
\hline & $\mathrm{R}$ & CCATTGTAGCACGTGTGTAGCC & & \\
\hline \multirow{2}{*}{ Ciliate protozoa } & $\mathrm{F}$ & GCTTTCGWTGGTAGTGTATT & \multirow{2}{*}{223} & \multirow{2}{*}{ [33] } \\
\hline & $\mathrm{R}$ & CTTGCCСTCYAATCGTWCT & & \\
\hline \multirow{2}{*}{ Fungi } & $\mathrm{F}$ & GAGGAAGTAAAAGTCGTAACAAGGTTTC & \multirow{2}{*}{120} & \multirow{2}{*}[32]{} \\
\hline & $\mathrm{R}$ & CAAATTCACAAAGGGTAGGATGATT & & \\
\hline \multirow{2}{*}{ Methanogenic archaea } & F & GAGGAAGGAGTGGACGACGGTA & \multirow{2}{*}{232} & \multirow{2}{*}[33]{} \\
\hline & $\mathrm{R}$ & ACGGGCGGTGTGTGCAAG & & \\
\hline \multirow{2}{*}{ Fibrobacter succinogenes } & $\mathrm{F}$ & GTTCGGAATTACTGGGCGTAAA & \multirow{2}{*}{121} & \multirow{2}{*}{ [32] } \\
\hline & $\mathrm{R}$ & CGCCTGCCCCTGAACTATC & & \\
\hline \multirow{2}{*}{ Ruminococcus albus } & $\mathrm{F}$ & CССTAAAAGCAGTCTTAGTTCG & \multirow{2}{*}{176} & \multirow{2}{*}[34]{} \\
\hline & $\mathrm{R}$ & CCTCCTTGCGGTTAGAACA & & \\
\hline \multirow{2}{*}{$\begin{array}{l}\text { Ruminococcus } \\
\text { flavefaciens }\end{array}$} & $\mathrm{F}$ & CGAACGGAGATAATTTGAGTTTACTTAGG & \multirow{2}{*}{132} & \multirow{2}{*}[32]{} \\
\hline & $\mathrm{R}$ & CGGTCTCTGTATGTTATGAGGTATTACC & & \\
\hline \multirow{2}{*}{ Prevotella ruminicola } & $\mathrm{F}$ & GCGAAAGTCGGATTAATGCTCTATG & \multirow{2}{*}{78} & \multirow{2}{*}{ [33] } \\
\hline & $\mathrm{R}$ & CССATCCTATAGCGGTAAACCTTTG & & \\
\hline \multirow{2}{*}{ Butyrivibrio fibrisolvens } & $\mathrm{F}$ & ACCGCATAAGCGCACGGA & \multirow{2}{*}{65} & \multirow{2}{*}{ [35] } \\
\hline & $\mathrm{R}$ & CGGGTCCATCTTGTACCGATAAAT & & \\
\hline \multirow{2}{*}{$\begin{array}{l}\text { Butyrivibrio } \\
\text { proteoclasticus }\end{array}$} & $\mathrm{F}$ & TCCGGTGGTATGAGATGGGC & \multirow{2}{*}{185} & \multirow{2}{*}{ [36] } \\
\hline & $\mathrm{R}$ & GTCGCTGCATCAGAGTTTCCT & & \\
\hline \multirow{2}{*}{ Anearovibrio lipolytica } & $\mathrm{F}$ & TGGGTGTTAGAAATGGATTC & \multirow{2}{*}{597} & \multirow{2}{*}{ [37] } \\
\hline & $\mathrm{R}$ & СТСТССТGСАСТСАAGAАTT & & \\
\hline
\end{tabular}

For absolute quantification of each microbe, PCR cloning was performed using each of the primers described in Table 1 to obtain a standard plasmid containing each target gene sequence.

The copy number of each standard primer was calculated [38]. If the molecular weight of the plasmid and insert is known, it is possible to calculate the copy number as follows:

Weight in daltons $(\mathrm{g} / \mathrm{mol})=(\mathrm{bp}$ size of $\mathrm{ds}$ product $)(330 \mathrm{Da} \times 2 \mathrm{nt} / \mathrm{bp})$

Hence: $(\mathrm{g} / \mathrm{mol}) /$ Avogadro's number $=\mathrm{g} /$ molecule $=$ copy number where: $\mathrm{bp}=$ base pairs, $\mathrm{ds}=$ double-stranded, $\mathrm{nt}=$ nucleotides.

CFX manager software (Bio-Rad, USA) was used to compare microbe quantifications with the standard curve.

\subsection{Statistical Analysis}

The effects of antioxidants and nitric oxide were decomposed into three orthogonal polynomial contrasts (linear, quadratic and cubic). Coefficients were generated using the IML procedure in Statistical Analysis System (SAS 9.4 Institute Inc., Cary, NC, USA) [39]. Duncan's multiple comparison test was used to investigate significant differences between 
the sample means. An independent-samples $t$-test was conducted to test the significance of differences in the effects of OLs on the in vitro rumen fermentation, rumen microbial populations, and $\mathrm{CH}_{4}$ production. Results with a $p$ value of $<0.05$ were considered statistically significant, and results with a $0.05 \leq p$ value $<0.1$ were considered to have tendency.

\section{Results}

\subsection{Chemical Composition of OLs and Their Total Phenolic and Flavonoid Contents}

To determine the quality of the OLs used in the study, we analyzed their chemical composition. The mean values of the chemical components are presented in Table 2. The mean values of the different components are expressed as the mean \pm standard deviation. The components of DM, CP, and EE were $94.59 \% \pm 0.03 \%, 8.8 \% \pm 0.30 \%$, and $10.87 \% \pm 0.49 \%$, respectively. The CA content was $8.28 \pm 0.17 \%$, NDF and ADF contents were $38.82 \pm 0.81 \%$ and $27.35 \pm 0.11 \%$, respectively.

Table 2. Chemical composition and antioxidant activity of olive leaves (OLs) (DM basis, \%).

\begin{tabular}{lc}
\multicolumn{1}{c}{ Items } & Olive leaves (Mean \pm SEM) \\
\hline Chemical composition & \\
\hline Dry matter (DM) & $94.59 \pm 0.03$ \\
Crude protein & $10.87 \pm 0.49$ \\
Ether extract & $8.80 \pm 0.30$ \\
Crude ash & $8.28 \pm 0.17$ \\
Neutral detergent fiber & $38.82 \pm 0.81$ \\
Acid detergent fiber & $27.35 \pm 0.11$ \\
\hline Antioxidant activity & \\
\hline Total polyphenol $(\mathrm{mg}$ catechin/g extract) & $34.79 \pm 2.72$ \\
Total flavonoid $(\mathrm{mg}$ quercetin/g extract) & $5.91 \pm 0.24$ \\
${\text { IC50 for DPPH }(\mu \mathrm{g} / \mathrm{mL})^{1}}{\text { IC50 for ABTS }(\mu \mathrm{g} / \mathrm{mL})^{2}}^{2}$ & 78.14 \\
\hline
\end{tabular}

${ }^{1}$ IC50: DPPH: 2,2-Diphenyl-1-picrylhydrazyl radical scavenging activity; ${ }^{2}$ ABTS: 2,2'-Azino-bis (3-ethylbenzothiazoline6-sulfonic acid) radical scavenging activity. SEM: standard error of the mean.

The total phenolic and total flavonoid content in OLs was $34.79 \pm 2.72 \mathrm{mg}$ catechin/g and $5.91 \pm 0.24 \mathrm{mg}$ quercetin/g, respectively (Table 2). The IC50 of 2,2-diphenyl-1picrylhydrazyl (DPPH) and 2,2'-azino-bis(3-ethylbenzothiazoline-6-sulfonic acid (ABTS) of the standard was 78.14 and $33.21 \mu \mathrm{g} / \mathrm{mL}$, respectively. Olive leaves (OLs) tended to show a relatively higher antioxidant activity at high concentrations $(10,50,100$, and $200 \mu \mathrm{g} / \mathrm{mL})$. All homeostatic activities were highest at a concentration of $200 \mu \mathrm{g} / \mathrm{mL}$. The hydroxyl (HO) radical-scavenging activity was high compared to other scavenging activities (Table 3 ). The antioxidant and NO radical inhibition effect of the extract at $200 \mu \mathrm{g} / \mathrm{mL}$ concentration was detected using the DPPH (54.25\%), ABTS (92.36\%), HO (596.4\%), and NO (27.94\%) assays.

\subsection{Carbohydrate Composition in OLs}

Olive leaves (OLs) contained sucrose (39.71\%) as the dominant carbohydrate, followed by sorbitol $(26.30 \%)$ and glucose $(10.42 \%)$. In this analysis, $62 \%$ of the metabolites identified as a whole were carbohydrate classes (CHO) (Table 4). 
Table 3. Antioxidant capacities (DPPH, ABTS, HO) and nitric oxide (NO) inhibition of olive leaves (OLs) (DM basis, \%).

\begin{tabular}{|c|c|c|c|c|c|c|c|c|c|}
\hline \multirow{2}{*}{ Content $^{1}$} & \multicolumn{4}{|c|}{ Plant Concentration $(\mu \mathrm{g} / \mathrm{mL}$, Mean \pm SEM) } & \multirow{2}{*}{ SEM $^{2}$} & \multirow{2}{*}{$\begin{array}{c}p- \\
\text { Value }\end{array}$} & \multicolumn{3}{|c|}{ Contrast $^{3}$} \\
\hline & 10 & 50 & 100 & 200 & & & L & $\mathbf{Q}$ & $\mathrm{C}$ \\
\hline DPPH & $33.18 \pm 1.52^{c}$ & $47.37 \pm 1.15^{b}$ & $53.21 \pm 0.81^{\mathrm{a}}$ & $54.25 \pm 0.43^{a}$ & 1.06 & & $<0.0001$ & $<0.0001$ & 0.0434 \\
\hline ABTS & $82.40 \pm 0.94^{\mathrm{d}}$ & $87.84 \pm 0.24^{c}$ & $90.80 \pm 0.09^{b}$ & $92.36 \pm 0.11^{\mathrm{a}}$ & 0.38 & $<0.0001$ & $<0.0001$ & $<0.0001$ & 0.0859 \\
\hline $\mathrm{HO}$ & $63.62 \pm 0.47^{\mathrm{d}}$ & $104.15 \pm 0.12^{c}$ & $265.78 \pm 0.04^{b}$ & $596.4 \pm 0.06^{\mathrm{a}}$ & 6.18 & $<0.0001$ & $<0.0001$ & $<0.0001$ & 0.0004 \\
\hline $\mathrm{NO}$ & $15.29 \pm 0.75^{\mathrm{d}}$ & $19.75 \pm 1.07^{\mathrm{c}}$ & $23.85 \pm 0.33^{b}$ & $27.94 \pm 0.46^{\mathrm{a}}$ & 0.71 & $<0.0001$ & $<0.0001$ & 0.0087 & 0.9259 \\
\hline
\end{tabular}

${ }^{1}$ Content: DPPH, 2,2-Diphenyl-1-picrylhydrazyl radical scavenging activity; ABTS, 2,20-Azino-bis(3-ethylbenzothiazoline-6-sulfonic acid) radical scavenging activity; $\mathrm{HO}$, hydroxyl radical scavenging activity; $\mathrm{NO}$, nitric oxide $(\mathrm{NO})$ inhibition. ${ }^{2}$ SEM: standard error of the mean.

${ }^{3}$ Contrast: L, linear; Q, quadratic; C, cubic effect. ${ }^{\mathrm{a}-\mathrm{d}}$ Means $(n=4)$ with different superscripts within a row differ significantly $(p<0.05)$.

Table 4. Carbohydrate, fatty acid, organic acid, and cyclic alcohol metabolites of olive leaves extracts (OLE) identified using GC-MS.

\begin{tabular}{|c|c|c|c|c|c|}
\hline RT (min) & Compound & Formula & Area (\%) & $\mathrm{MW}(\mathrm{g} / \mathrm{mol})^{1}$ & Class $^{2}$ \\
\hline 5.471 & Lactic acid & $\mathrm{C}_{3} \mathrm{H}_{6} \mathrm{O}_{3}$ & 0.38 & 90.080 & OA \\
\hline 8.894 & Glycerol & $\mathrm{C}_{3} \mathrm{H}_{8} \mathrm{O}_{3}$ & 0.72 & 92.094 & FA \\
\hline 16.497 & Fructose & $\mathrm{C}_{6} \mathrm{H}_{12} \mathrm{O}_{6}$ & 1.44 & 180.160 & $\mathrm{CHO}$ \\
\hline 16.599 & Fructose & $\mathrm{C}_{6} \mathrm{H}_{12} \mathrm{O}_{6}$ & 1.10 & 180.160 & $\mathrm{CHO}$ \\
\hline 16.704 & Galactose & $\mathrm{C}_{6} \mathrm{H}_{12} \mathrm{O}_{6}$ & 0.47 & 180.156 & $\mathrm{CHO}$ \\
\hline 16.77 & Glucose & $\mathrm{C}_{6} \mathrm{H}_{12} \mathrm{O}_{6}$ & 10.42 & 180.156 & $\mathrm{CHO}$ \\
\hline 16.981 & Glucose & $\mathrm{C}_{6} \mathrm{H}_{12} \mathrm{O}_{6}$ & 2.06 & 180.156 & $\mathrm{CHO}$ \\
\hline 17.12 & Sorbitol & $\mathrm{C}_{6} \mathrm{H}_{14} \mathrm{O}_{6}$ & 26.30 & 182.170 & $\mathrm{CHO}$ \\
\hline 17.189 & $\begin{array}{l}\text { Ethyl-alpha- } \\
\text { glucopyranoside }\end{array}$ & $\mathrm{C}_{8} \mathrm{H}_{16} \mathrm{O}_{6}$ & 3.57 & 208.210 & $\mathrm{CHO}$ \\
\hline 18.411 & Palmitic acid & $\mathrm{C}_{16} \mathrm{H}_{32} \mathrm{O}_{2}$ & 6.84 & 256.400 & OA \\
\hline 18.778 & Myo-inositol & $\mathrm{C}_{6} \mathrm{H}_{12} \mathrm{O}_{6}$ & 0.95 & 180.160 & CA \\
\hline 20.309 & Stearic acid & $\mathrm{C}_{18} \mathrm{H}_{36} \mathrm{O}_{2}$ & 6.04 & 284.480 & $\mathrm{OA}$ \\
\hline 23.552 & Sucrose & $\mathrm{C}_{12} \mathrm{H}_{22} \mathrm{O}_{11}$ & 39.71 & 342.300 & $\mathrm{CHO}$ \\
\hline
\end{tabular}

${ }^{1}$ MW: molecular weight; ${ }^{2}$ Class: OA, organic acid; FA, fatty acid; $\mathrm{CHO}$, carbohydrate; $\mathrm{CA}$, cyclic alcohol.

\subsection{In Vitro Batch Fermentation}

The $\mathrm{pH}$ of OLs ranged from 6.61 to 7.28 . The $\mathrm{pH}$ at $12 \mathrm{~h}$ was 7.11 and 7.28 in the control and 5\% OLs groups, respectively; the $\mathrm{pH}$ was 6.61 and 6.66 in the control and $5 \%$ OLs groups at $24 \mathrm{~h}$, respectively.

There was no significant difference in the MGR between the $5 \%$ OLs group and control group at $24 \mathrm{~h}(p>0.05)$.

Dry matter digestion was affected by feed supplemented with $5 \%$ OLs after 12 and $24 \mathrm{~h}$ of incubation $(p<0.05)$. Dry matter degradation after 12 and $24 \mathrm{~h}$ was significantly reduced in the $5 \%$ OLs groups.

The concentration of ammonia $\left(\mathrm{NH}_{3}\right)$ was significantly increased in the $5 \%$ OLs group $(p<0.05)$.

Olive leaves (OLs) showed similar molar percentages of acetate and propionate at 12 and $24 \mathrm{~h}$. The acetate-to-propionate $(\mathrm{A} / \mathrm{P})$ ratio was high in the control group at $12 \mathrm{~h}$ and significantly higher in $(p=0.0029)$ the $5 \%$ OLs group at $24 \mathrm{~h}$. Moreover, the total VFA $(p=0.0023)$ and acetate $(p=0.0002)$ content in the 5\% OLs group was higher than that in the control group at $12 \mathrm{~h}$, and there was no significant difference in the propionate content between the groups $(p>0.05)$ (Table 5). 
Table 5. Effects of 5\% olive leaves (OLs) on in vitro gas production and fermentation characteristics at 12 and $24 \mathrm{~h}$.

\begin{tabular}{|c|c|c|c|c|}
\hline \multirow{2}{*}{ Parameters ${ }^{1}$} & \multicolumn{2}{|c|}{ Treatments } & \multirow{2}{*}{ SEM $^{2}$} & \multirow{2}{*}{$p$ Value } \\
\hline & Control & $5 \%$ OLs & & \\
\hline \multicolumn{5}{|l|}{$12 \mathrm{~h}$} \\
\hline $\mathrm{pH}$ & $7.11^{b}$ & $7.28^{a}$ & 0.02 & 0.0020 \\
\hline $\mathrm{DMD}(\%)$ & $38.00^{\mathrm{a}}$ & $33.67^{b}$ & 1.07 & 0.0459 \\
\hline MGR (OD $550 \mathrm{~nm}$ ) & 0.30 & 0.26 & 0.01 & 0.0843 \\
\hline Ammonia $\left(\mathrm{mg} \cdot \mathrm{dL}^{-1}\right)$ & $9.80^{b}$ & $13.49^{\mathrm{a}}$ & 0.25 & $<0.0001$ \\
\hline Total VFA $(\mathrm{mM})$ & $48.73^{\mathrm{a}}$ & $45.54^{b}$ & 0.45 & 0.0023 \\
\hline Acetate (mM) & $31.54^{\mathrm{a}}$ & $29.28^{b}$ & 0.19 & 0.0002 \\
\hline Propionate (mM) & 9.72 & 9.59 & 0.11 & 0.4291 \\
\hline Butyrate (mM) & $7.47^{\mathrm{a}}$ & $6.67^{b}$ & 0.19 & 0.0238 \\
\hline $\mathrm{A} / \mathrm{P}$ ratio & $3.24^{\mathrm{a}}$ & $3.05^{b}$ & 0.03 & 0.0022 \\
\hline \multicolumn{5}{|l|}{$24 \mathrm{~h}$} \\
\hline $\mathrm{pH}$ & 6.61 & 6.66 & 0.02 & 0.3034 \\
\hline $\mathrm{DMD}(\%)$ & $51.92^{\mathrm{a}}$ & $49.17^{b}$ & 0.69 & 0.0311 \\
\hline MGR (OD $550 \mathrm{~nm}$ ) & 0.35 & 0.27 & 0.03 & 0.1557 \\
\hline Ammonia $\left(\mathrm{mg} \cdot \mathrm{dL}^{-1}\right)$ & $11.69^{b}$ & $13.02^{\mathrm{a}}$ & 0.19 & 0.0011 \\
\hline Total VFA (mM) & 63.26 & 62.85 & 0.16 & 0.1153 \\
\hline Acetate $(\mathrm{mM})$ & 41.75 & 41.64 & 0.20 & 0.6941 \\
\hline Propionate (mM) & $13.22^{\mathrm{a}}$ & $12.58^{b}$ & 0.05 & 0.0002 \\
\hline Butyrate (mM) & $8.28^{b}$ & $8.63^{a}$ & 0.10 & 0.0469 \\
\hline $\mathrm{A} / \mathrm{P}$ ratio & $3.16^{b}$ & $3.31^{\mathrm{a}}$ & 0.02 & 0.0029 \\
\hline
\end{tabular}

${ }^{1}$ Parameters: MGR, microbial growth rate; OD, optical density; DMD, dry matter digestibility; VFA, volatile fatty acid; A/P, acetate to propionate ratio. ${ }^{2}$ SEM: standard error of the means. ${ }^{\mathrm{a}, \mathrm{b}}$ Means $(n=3)$ with different superscripts within a row differ significantly $(p<0.05)$.

The amount of $\mathrm{CH}_{4}$ produced based on the amount of total VFA produced was determined, and it was confirmed that $\mathrm{CH}_{4}$ production was reduced in the OLs group at $12 \mathrm{~h}$. This result was consistent with the amount of $\mathrm{CH}_{4}$ produced via in vitro batch fermentation.

Methane $\left(\mathrm{CH}_{4}\right)$ emission at $12 \mathrm{~h}$ was significantly lower in the $5 \%$ OLs group $(18.19 \mathrm{~mL} / \mathrm{g}$ $\operatorname{dig} \mathrm{DM}, p<0.0001)$ than in the control group $(27.63 \mathrm{~mL} / \mathrm{g}$ dig DM, $p=0.0006)$. The total gas and $\mathrm{CO}_{2}$ emissions were similar to the pattern of $\mathrm{CH}_{4}$ emission, and were low in the $5 \%$ OLs group (Figure 1).

\subsection{Antibacterial Activity}

Antibacterial activity was measured against Staphylococcus aureus, Escherichia coli, Klebsiella pneumoniae, and Pseudomonas aeruginosa via paper disc diffusion assays; the results are shown in Table 6 and Figure S1. The 5\% OLs fraction showed the highest activity against $S$. aureus. These findings confirmed that OLs had antibacterial activity against pathogenic bacteria. 
$12 \mathrm{~h}$ Gas profiles

(A)

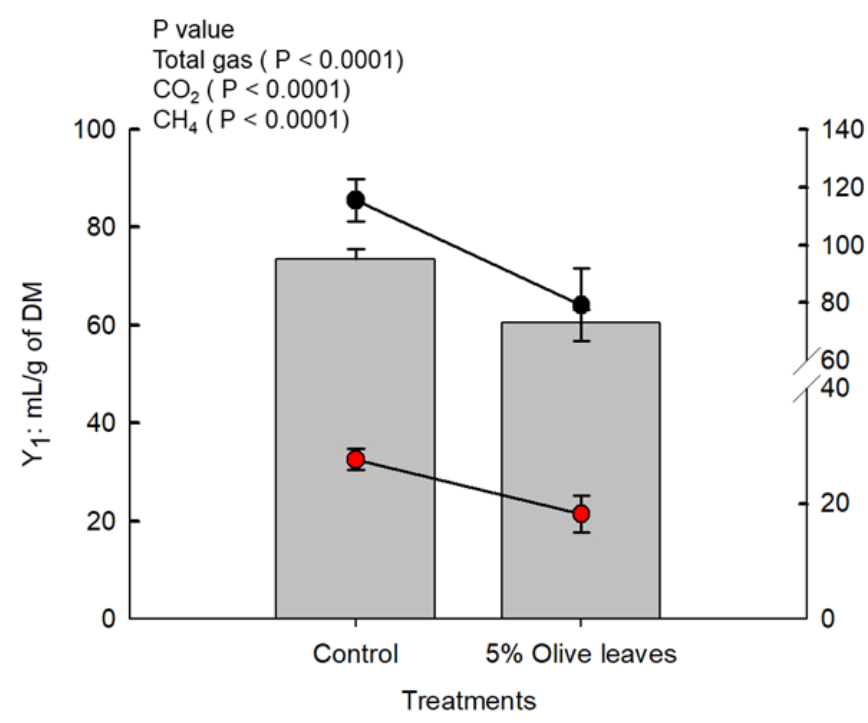

$24 \mathrm{~h}$ Gas profiles

(B)

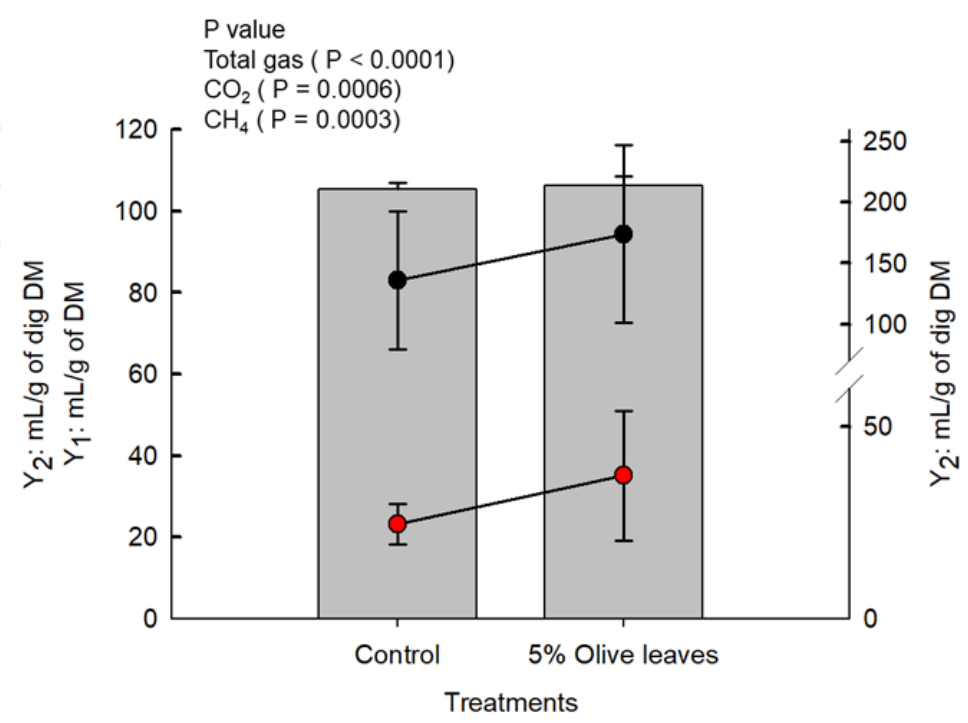

\section{Total gas}

\section{$\mathrm{CO}_{2} \multimap \mathrm{CH}_{4}$}

Figure 1. Effects of $5 \%$ olive leaves (OLs) on gas profile at (A) 12 and (B) $24 \mathrm{~h}$. $\mathrm{Y}_{1}$ axis represents gas production unit (mL/g of DM) and $\mathrm{Y}_{2}$ axis represents gas production unit (mL/g of dig DM). Error bars indicate standard error of the mean $(n=3)$.

Table 6. Antimicrobial activities of $5 \%$ olive leaves (OLs) fractions.

\begin{tabular}{ccccc}
\hline \multirow{2}{*}{ Paper Disk } & \multicolumn{4}{c}{ Microorganisms Tested } \\
\cline { 2 - 5 } & $\begin{array}{c}\text { Staphylococcus } \\
\text { aureus } \\
\text { ATCC 6538 }\end{array}$ & $\begin{array}{c}\text { Escherichia Coli } \\
\text { ATCC 8739 }\end{array}$ & $\begin{array}{c}\text { Klebsiella } \\
\text { Pneumoniae } \\
\text { ATCC 4352 }\end{array}$ & $\begin{array}{c}\text { Pseudomonas } \\
\text { aeruginosa } \\
\text { ATCC 10145 }\end{array}$ \\
\hline $\begin{array}{c}\text { Conc. } \\
(\mu \mathrm{g} / \text { disc })\end{array}$ & 50 & 50 & 50 & 50 \\
$\begin{array}{c}\text { Clear Zone } \\
(\mathrm{mm})\end{array}$ & 10 & 8 & 8.5 & 8 \\
\hline
\end{tabular}

\subsection{Effect of OLs on the Microbial Composition on In Vitro Batch Fermentation}

The absolute value of total bacteria in the $5 \%$ OLs group was significantly lower than control group (Table 7). Olive leaves (OLs) supplementation reduced the total bacteria at both 12 and $24 \mathrm{~h}$. The abundance of fungi decreased in the 5\% OLs group at $24 \mathrm{~h}$, and the abundance of ciliate protozoa was unaffected via OLs group. The absolute value of methanogenic archaea did not differ at $12 \mathrm{~h}$, and was significantly lower at $24 \mathrm{~h}(p<0.0001)$. The relative proportions of fibrolytic bacteria including $R$. albus and $R$. flavefaciens and that of P. ruminicola tended to increase at $12 \mathrm{~h}$ in the $5 \%$ OLs group compared to controls. However, most microorganisms showed the opposite trend at $24 \mathrm{~h}$ compared to that observed at $12 \mathrm{~h}$. The absolute values of $F$. succinogenes and $R$. albus were high in the $24 \mathrm{~h}$ control group $(p<0.0001)$. There was no significant difference in the proportion of $R$. flavefaciens at $24 \mathrm{~h}$. The abundance of proteolytic bacteria including $B$. fibrisolvens and $B$. proteoclasticus was significantly lower in the $5 \%$ OLs group than in the control group. In addition, the relative proportion of fat-utilizing bacteria, A. lipolytica, was significantly higher in the $5 \%$ OLs group $(p<0.0001)$. 
Table 7. Effect of 5\% olive leaves (OLs) on the relative quantification of rumen microorganism populations under in vitro ruminal fermentation for 12 and $24 \mathrm{~h}$.

\begin{tabular}{|c|c|c|c|c|c|}
\hline Items & $\begin{array}{l}\text { Fermentation } \\
\text { Time (h) }\end{array}$ & Control & $5 \%$ Olive leaves & SEM $^{1}$ & $p$-Value \\
\hline \multicolumn{6}{|l|}{ Absolute abundance ${ }^{2}$} \\
\hline \multirow[t]{2}{*}{ Total bacteria } & 12 & $3.17^{\mathrm{a}}$ & $2.38^{b}$ & 0.15 & 0.0212 \\
\hline & 24 & $4.65^{\mathrm{a}}$ & $2.70^{\mathrm{b}}$ & 0.38 & 0.0216 \\
\hline \multirow[t]{2}{*}{ Fungi } & 12 & 34.63 & 33.69 & 10.90 & 0.9543 \\
\hline & 24 & $5.52^{\mathrm{a}}$ & $0.66^{\mathrm{b}}$ & 0.70 & 0.0079 \\
\hline \multirow[t]{2}{*}{ Ciliate protozoa } & 12 & 1.45 & 3.82 & 0.85 & 0.1184 \\
\hline & 24 & 0.97 & 1.09 & 0.43 & 0.8569 \\
\hline \multirow[t]{2}{*}{ Methanogenic archaea } & 12 & 10.15 & 8.87 & 0.90 & 0.3712 \\
\hline & 24 & $16.60^{\mathrm{a}}$ & $5.84^{\mathrm{b}}$ & 0.36 & $<0.0001$ \\
\hline \multicolumn{6}{|c|}{ Relative proportion, $\%$ total bacteria } \\
\hline \multirow[t]{2}{*}{ Fibrobacter succinogenes } & 12 & 10.54 & 10.98 & 1.44 & 0.8313 \\
\hline & 24 & $13.20^{\mathrm{a}}$ & $0.53^{b}$ & 0.38 & $<0.0001$ \\
\hline \multirow[t]{2}{*}{ Ruminococcus albus } & 12 & $4.27^{\mathrm{b}}$ & $24.12^{\mathrm{a}}$ & 0.54 & $<0.0001$ \\
\hline & 24 & $5.29^{a}$ & $2.23^{b}$ & 0.34 & $<0.0001$ \\
\hline \multirow[t]{2}{*}{ Ruminococcus flavefaciens } & 12 & $0.86^{b}$ & $1.02^{\mathrm{a}}$ & 0.03 & 0.0012 \\
\hline & 24 & 0.66 & 0.63 & 0.02 & 0.2469 \\
\hline \multirow[t]{2}{*}{ Prevotella ruminicola } & 12 & $26.22^{b}$ & $31.04^{\mathrm{a}}$ & 1.48 & 0.0349 \\
\hline & 24 & $38.97^{a}$ & $28.09^{b}$ & 1.07 & $<0.0001$ \\
\hline \multirow[t]{2}{*}{ Butyrivibrio fibrisolvens } & 12 & $1.99^{\mathrm{a}}$ & $1.17^{\mathrm{b}}$ & 0.08 & 0.0012 \\
\hline & 24 & $2.78^{a}$ & $1.26^{\mathrm{b}}$ & 0.21 & 0.2469 \\
\hline \multirow[t]{2}{*}{ Butyrivibrio proteoclasticus } & 12 & $0.36^{\mathrm{a}}$ & $0.26^{\mathrm{b}}$ & 0.01 & $<0.0001$ \\
\hline & 24 & $0.46^{\mathrm{a}}$ & $0.32^{b}$ & 0.01 & $<0.0001$ \\
\hline \multirow[t]{2}{*}{ Anearovibrio lipolytica } & 12 & $0.26^{\mathrm{b}}$ & $1.16^{\mathrm{a}}$ & 0.08 & $<0.0001$ \\
\hline & 24 & $0.93^{b}$ & $4.34^{\mathrm{a}}$ & 0.27 & $<0.0001$ \\
\hline
\end{tabular}

${ }^{1} \mathrm{SEM}$, standard error of the mean. ${ }^{2}$ Total bacteria, $\times 10^{10}$ copies $/ \mathrm{mL}$ of ruminal fluid; fungi, $\times 10^{6}$ copies $/ \mathrm{mL}$ of ruminal fluid; ciliate protozoa, $\times 10^{9}$ copies $/ \mathrm{mL}$ of ruminal fluid; methanogenic archaea, $\times 10^{9}$ copies $/ \mathrm{mL}$ of ruminal fluid; ${ }^{\mathrm{a}, \mathrm{b}}$ means $(n=3)$ with different superscripts within a row differ significantly $(p<0.05)$.

\section{Discussion}

The chemical composition of OLs was investigated. According to Molina-Alcaide et al., the chemical composition in OLs (g/kg DM) comprises DM (777), EE (56.4), CP (100), mild detergent fiber (406), and ADF (302). In this study, the composition ( $\mathrm{g} / \mathrm{kg} \mathrm{DM})$ included DM (945.9), CP (108.7), EE (88), NDF (388), and ADF (273.5), which was similar to that reported in literature.

Olive leaves extract (OLE) has been found to contain antibacterial and antioxidant properties [40]. Brahmi et al. [41] suggested that the antibacterial activity of OLs is related to the terpene content. In this study, the terpene-based polyphenol content was found to be $34.79 \mathrm{mg}$ catechin/g and the flavonoid content was $5.91 \mathrm{mg}$ quercetin/g. Terpenes are known to disrupt cell membranes [42]. Olive leaves extract (OLE) has been shown to regulate the composition of gastric bacteria by selectively reducing the levels of Campylobacter jejuni and Helicobacter pylori [43]. Although many studies have investigated the antibacterial activity of OLs, the mechanism of action of the antimicrobial activity has not been fully elucidated [40]. Olive leaves extract (OLE) has been found to show antibacterial activity against S. aureus, E. coli, and Salmonella spp.; a particularly high antimicrobial activity is observed against Listeria monocytogenes [44].

We found that digestibility in the in vitro batch was significantly lower in the OLs group than in the control group. According to Molina-Alcaide et al. [11], information on rumen $\mathrm{CP}$ decomposition after OLs supplementation is scarce, and the reported values are low and the variance is large. Olive leaves (OLs) and olive cake show low ruminal decomposition in both sheep and goats. Moreover, the addition of polyethylene glycol to olive byproducts increases rumen-derived microbial nitrogen, fermentation properties, and the degradability of DM [11]. 
Olive leaves extract (OLE) using chloroform has various physiological activities, and contains a large amount of secondary compounds, such as phenolic compounds and condensed tannins. It is also effective in reducing $\mathrm{CH}_{4}$ production without affecting the VFA concentration [13]. Shakeri et al. [13] reported that the addition of OLs to in vitro fermentation reduces $\mathrm{CH}_{4}$ emissions in the rumen by 15-53\% compared to that in the control. Olive leaves (OLs) group significantly reduces the $\mathrm{A} / \mathrm{P}$ ratio by increasing propionate production, which activates the pathway for reducing $\mathrm{CH}_{4}$ production. Molina-Alcaide et al. [10] tested continuous culture fermenters and reported that the A/P ratio is lower when using diet containing OLs than that obtained using alfalfa hay. The decrease in the $\mathrm{A} / \mathrm{P}$ ratio via OLs addition may be due to the reduced growth of ruminant cellulolytic bacteria owing to antibacterial activity.

The reason why OLs are associated with a lower gas production and total VFA concentration than those obtained using the control may be attributed to their low nutritional value [11]. Phenolic compounds in OLs are known to affect fermentation. In addition, these phenolic compounds show antimicrobial effects against ruminant microbes, thereby reducing the overall microbial activity in a similar way $[45,46]$. In this study, we found that the total VFA decreased, and the phenolic compounds present in OLs interfered with the activity of ruminant microorganisms. The $80 \%$ ethanol extract, butanol, and ethyl acetate fractions of OLs inhibited the growth of Bacillus cereus, S. aureus, E. coli, and Salmonella enteritidis; however, the hexane and chloroform fractions did not show antibacterial activity. OLs at concentrations of $<100 \mu \mathrm{g} /$ disc do not exert antibacterial effects against Bacillus cereus, S. aureus, E. coli, and Salmonella enteritidis, and at the concentration of 400-800 $\mu \mathrm{g} / \mathrm{disc}$, the size of clear zones of inhibition is 11-20 mm [47].

The bacterial inhibition activity was assessed based on the clear zone diameter as follows: very strong $(>20 \mathrm{~mm})$, strong $(10-20 \mathrm{~mm})$, medium $(5-10 \mathrm{~mm})$, and weak $(<5 \mathrm{~mm})$ [48]. In this study, zones of inhibition of sizes 8-10 $\mathrm{mm}$ were obtained when bacteria were inoculated with $50 \mu \mathrm{g}$ of OLs group. The antibacterial effect increased with an increase in concentration of OLs group. We detected antibacterial activity despite a low concentration. Lee et al. [47] suggested that the butanol and ethyl acetate fractions containing high contents of flavonoids, total phenols, and phenolic compounds show potent antimicrobial activity, suggesting that there is a correlation between antibacterial activity and phenolic substances. The antimicrobial activity of OLs is often associated with its major phenolic component, alleuropein [49]. Lee-Huang et al. [49] reported that phenolic compounds such as rutin, verbascoside, luteolin-7-glucoside, apigenin-7-glucoside, oleuropein, and oleuroside are present in OLs, and that only oleropein and oleuroside are capable of anti-HIV activity. In addition, the results of antimicrobial activity are also linked to a decrease in digestibility, which may be due to a high fat content and a large amount of phenolic compounds, resulting in a decrease in digestibility, thereby decreasing the total gas emission. However, these naturally derived substances do not have long-lasting and potent antioxidant and antimicrobial effects. Therefore, the growth of microorganisms and the amount of gas generated may have increased within $24 \mathrm{~h}$ [50]. At $12 \mathrm{~h}$ of fermentation, the production of $\mathrm{CH}_{4}$ decreased $(p<0.0001)$ compared to the control in the $5 \%$ OLs group, but not at $24 \mathrm{~h}$. Therefore, the effect of OLs slowing down $\mathrm{CH}_{4}$ production was not long-lasting. The addition of plant-derived oils to feed can affect ruminant microorganisms. Ernesto Vargas et al. [51] showed that the total bacterial count was significantly reduced. This is consistent with reports that OLs has antibacterial properties [43]. This is an important result of examining the antibacterial mechanism of OLs against ruminal fluid. The total bacterial count decreased at both 12 and $24 \mathrm{~h}$ in the OLs group $(p=0.021)$.

The abundance of fungi decreased 8.4-fold in the OLs group at $24 \mathrm{~h}$. Several studies have reported that a high-fat diet reduces the population of protozoa; however, there was no significant difference in this study. The proportion of protozoa in the rumen of OLs-fed animals is lower than that in standard diet-fed animals, possibly due to a lack of water-soluble carbohydrates and a high content of unsaturated fatty acids present in 
OLs. However, supplementation of OLs with barley grains or faba beans is associated with adequate microbial activity in goats and sheep [15].

The proportion of methanogenic archaea in the OLs group was 2.8-fold lower than that in the control group at $24 \mathrm{~h}$. The reason $\mathrm{CH}_{4}$ emission did not decrease at $24 \mathrm{~h}$ despite the decrease in the proportion of methanogenic archaea may be partly due to the relative abundance of $\mathrm{CH}_{4}$-producing archaea in the rumen [52].

The proportion of cellulose-degrading bacteria, F. succinogenes, R. albus, and R. flavefaciens, tended to increase in the OLs group at $12 \mathrm{~h}$ and decreased at $24 \mathrm{~h}$. P. ruminicola is known to degrade hemicellulose and produce $\mathrm{NH}_{3}$ [53]. In this study, the amount of $\mathrm{NH}_{3}$ produced was the same as the microbial composition result for P. ruminicola. At $12 \mathrm{~h}$, the proportion of P. ruminicola was significantly higher in the $5 \%$ OLs group than that in the control group. The amount of $\mathrm{NH}_{3}$ produced increased over $12 \mathrm{~h}$. In addition, even with the decrease in P. ruminicola abundance at $24 \mathrm{~h}, \mathrm{NH}_{3}$ levels were high in the $5 \%$ OLs group. The content of $\mathrm{NH}_{3}$ was higher in the $5 \%$ OLs group than in the control. In the $5 \%$ OLs group, there was no difference in the $\mathrm{NH}_{3}$ content with time, with values of 13.49 and $13.02 \mathrm{mg} \cdot \mathrm{dL}^{-1}$ at 12 and $24 \mathrm{~h}$, respectively. Presumably, P. ruminicola abundance was higher in the $12 \mathrm{~h} 5 \%$ OLs group than in the control group, where OLs addition had more protein sources than the control group.

The proportion of proteolytic bacteria, B. fibrisolvens and B. proteoclasticus, was found to be low in the $5 \%$ OLs group, which may be attributed to the low protein content in OLs. When OLs with relatively high fatty acid content were used, the abundance of lipolytic bacteria such as $A$. lipolytica was significantly higher in the $5 \%$ OLs group. Olive leaves (OLs) may be fully utilized as a high-energy feed by supplementing protein and feeding OLs at an appropriate ratio.

\section{Conclusions}

Several byproducts of olives have been identified and studied; however, the byproducts related to OLs have not been studied for their use as feed for livestock. Olive leaves (OLs) have a higher polyphenol content than that in olives, and when byproducts are provided as feed, they exhibit antibacterial effects against pathogenic bacteria and antioxidant effects in animals. In this study, it was confirmed that $\mathrm{CH}_{4}$ emission decreased during $12 \mathrm{~h}$ of in vitro fermentation, and the number of fat-utilizing microorganisms increased in the $5 \%$ OLs group. Consumption of these byproducts, during the currently faced issues of climate change, may present a viable strategy. In addition, OLs are considered as good feed additives for ruminants when supplemented with proteins. Future studies should evaluate supplements comprising OLs and proteins.

Supplementary Materials: The following are available online at https://www.mdpi.com/article/ 10.3390/ani11072008/s1. Figure S1: Antibacterial activities of olive leaves against Gram-positive and negative bacteria. Gram-positive bacteria: a: Staphylococcus aureus (ATCC 6538), Gram-negative bacteria: b: Escherichia Coli (ATCC 8739), c: Klebsiella pneumoniae (ATCC 4352), d: Pseudomonas aeruginosa (ATCC 10145).

Author Contributions: Conceptualization, S.J.L.; methodology, J.S., K.H.K., S.S.L.; formal analysis, H.S.K., J.S.E., Y.Y.C., S.U.J., G.M.C., Y.L.; data curation, S.J.L., S.S.L.; writing-original draft preparation, S.J.L., H.S.K.; writing—review and editing, S.J.L. and S.S.L.; software, S.J.L., H.S.K.; visualization, S.J.L.; funding acquisition, S.J.L.; supervision, S.S.L. All authors have read and agreed to the published version of the manuscript.

Funding: This study was supported by the National Institute of Animal Science, Ministry of Rural Development Administration, Republic of Korea (research project PJ01477803).

Institutional Review Board Statement: This study was conducted in accordance with the guidelines of the Animal Care and Use Committee of Gyeongsang National University (Gyeongsangnam-do, Jinju, Korea; GNU-180130-A0007).

Conflicts of Interest: The authors declare no conflict of interest. 


\section{References}

1. Tabera, J.; Guinda, A.; Ruiz-Rodríguez, A.; Señoráns, F.J.; Ibáñez, E.; Albi, T.; Reglero, G. Countercurrent supercritical fluid extraction and fractionation of high-added-value compounds from a hexane extract of olive leaves. J. Agric. Food Chem. 2004, 52, 4774-4779. [CrossRef] [PubMed]

2. Vogel, P.; Machado, I.K.; Garavaglia, J.; Zani, V.T.; de Souza, D.; Morelo dal Bosco, S. Polyphenols benefits of olive leaf (Olea europaea L.) to human health. Nutr. Hosp. 2015, 31, 1427-1433.

3. Nilüfer, A.T.; Ağagündüz, D. Olive leaf (Olea europaea L. folium): Potential effects on glycemia and lipidemia. Ann. Nutr. Metab. 2020, 76, 10-15.

4. Rosell'o-Soto, E.; Koubaa, M.; Moubarik, A.; Lopes, R.P.; Saraiva, J.A.; Boussetta, N.; Grimi, N.; Barba, F.J. Emerging opportunities for the effective valorization of wastes and by-products generated during olive oil production process: Nonconventional methods for the recovery of high-added value compounds. Trends Food Sci. Technol. 2015, 45, 296-310. [CrossRef]

5. Moudache, M.; Colon, M.; Nerín, C.; Zaidi, F. Phenolic content and antioxidant activity of olive by-products and antioxidant film containing olive leaf extract. Food Chem. 2016, 212, 521-527. [CrossRef]

6. Brahmi, F.; Mechri, B.; Dabbou, S.; Dhibi, M.; Hammami, M. Efficacy of phenolics compounds with different polarities as antioxidants from olive leaves depending on seasonal variations. Ind. Crops Prod. 2012, 38, 146-152. [CrossRef]

7. El, S.N.; Karakaya, S. Olive tree (Olea europaea) leaves: Potential beneficial effects on human health. Nutr. Rev. 2009, 67, 632-638. [CrossRef] [PubMed]

8. Bouaziz, M.; Fki, I.; Jemai, H.; Ayadi, M.; Sayadi, S. Effect of storage on refined and husk olive oils composition: Stabilization by addition of natural antioxidants from Chemlali olive leaves. Food Chem. 2008, 108, 253-262. [CrossRef]

9. Khayyal, M.T.; el-Ghazaly, M.A.; Abdallah, D.M.; Nassar, N.N.; Okpanyi, S.N.; Kreuter, M.H. Blood pressure lowering effect of an olive leaf extract (Olea europaea) in L-NAME induced hypertension in rats. Arzneimittelforschung 2002, 52, 797-802.

10. Martínez-Martos, J.M.; Mayas, M.D.; Carrera, P. Phenolic compounds oleuropein and hydroxytyrosol exert differential effects on glioma development via antioxidant defense systems. J. Funct. Foods 2014, 11, 221-234. [CrossRef]

11. Puel, C.; Mathey, J.; Agalias, A. Dose-response study of effect of oleuropein, an olive oil polyphenol, in an ovariectomy/inflammation experimental model of bone loss in the rat. Clin. Nutr. 2006, 25, 859-868. [CrossRef] [PubMed]

12. Molina-Alcaide, E.; Yáñez Ruiz, D.R. Potential use of olive by-products in ruminant feeding: A review. Anim. Feed. Sci. Technol. 2008, 147, 247-264. [CrossRef]

13. Shakeri, P.; Durmic, Z.; Vadhanabhuti, J.; Vercoe, P.E. Products derived from olive leaves and fruits can alter in vitro ruminal fermentation and methane production. J. Sci. Food Agric. 2017, 97, 1367-1372. [CrossRef]

14. Escalona, B.; Rocha, R.; García, J.; Carabano, R.; de-Blas, C. Characterization of in situ fibre digestion of several fibrous foods. Anim. Sci. 1999, 68, 217-221. [CrossRef]

15. Yáñez Ruiz, D.R.; Martín García, A.I.; Moumen, A.; Molina Alcaide, E. Ruminal fermentation and degradation patterns, protozoa population and urinary purine derivatives excretion in goats and wethers fed diets based on olive leaves. J. Anim. Sci. 2004, 82, 3006-3014. [CrossRef] [PubMed]

16. Martín García, A.I.; Moumen, A.; Yáñez Ruiz, D.R.; Molina Alcaide, E. Chemical composition and nutrients availability for goats and sheep of two-stage olive cake and olive leaves. Anim. Feed Sci. Technol. 2003, 107, 61-74. [CrossRef]

17. AOAC. Official Methods of Analysis, 15th ed.; Association of Official Analytical Chemists: Arlington, VA, USA, 1990.

18. Van Soest, P.J.; Robertson, J.B.; Lewis, B.A. Methods for dietary fiber, neutral detergent fiber, and nonstarch polysaccharides in relation to animal nutrition. J. Dairy Sci. 1991, 74, 3583-3597. [CrossRef]

19. Choi, Y.Y.; Lee, S.J.; Lee, Y.J.; Kim, H.S.; Eom, J.S.; Kim, S.C.; Kim, E.T.; Lee, S.S. New challenges for efficient usage of Sargassum fusiforme for ruminant production. Sci. Rep. 2020, 10, 19655. [CrossRef]

20. McDougall, E.I. Studies on ruminant saliva. 1. The composition and output of sheep's saliva. Biochem. J. 1948, 43, 99-109. [CrossRef] [PubMed]

21. Singleton, V.L.; Rossi, J.R. Colorimetry of total phenolics with phosphomolybdic-phosphotungstic acid reagents. Am. J. Enol. Vitic. 1965, 16, 144-158.

22. Meda, A.; Lamien, C.E.; Romito, M.; Millogo, J.; Nacoulma, O.G. Determination of the total phenolic, flavonoid and proline contents in Burkina Fasan honey, as well as their radical scavenging activity. Food Chem. 2005, 91, 571-577. [CrossRef]

23. Brand-Williams, W.; Cuvelier, M.E.; Berset, C. Use of a free radical method to evaluate antioxidant activity. LWT Food Sci. Technol. 1995, 28, 25-30. [CrossRef]

24. Re, R.; Pellegrini, N.; Proteggente, A.; Pannala, A.; Yang, M.; Rice-Evans, C. Antioxidant activity applying an improved ABTS radical cation decolorization assay. Free Radic. Biol. Med. 1999, 26, 1231-1237. [CrossRef]

25. Elizabeth, K.; Rao, M.N.A. Oxygen radical scavenging activity of curcumin. Int. J. Pharm. 1990, 58, $237-240$.

26. Lee, H.S. Antioxidative activity of browning reaction products isolated from storage-aged orange juice. J. Agric. Food Chem. 1992, 40, 550-552. [CrossRef]

27. Kalemba, D.; Kunicka, A. Antibacterial and antifungal properties of essential oils. Curr. Med. Chem. 2003, 10, 813-829.

28. European Medicines Agency. Harmonisation of European Breakpoints Set by MEA/CHMP and EUCAST; EMEA: London, UK, 2005.

29. Li, Y.; Sun, M.; Li, Y.; Cheng, Y.; Zhu, W. Co-cultured methanogen improved the metabolism in the hydrogenosome of anaerobic fungus as revealed by gas chromatography-mass spectrometry analysis. Asian Australas. J. Anim. Sci. 2020, 33, 1948-1956. [CrossRef] [PubMed] 
30. Kim, D.H.; Lee, S.J.; Oh, D.S.; Lee, I.D.; Eom, J.S.; Park, H.Y.; Choi, S.H.; Lee, S.S. In vitro evaluation of Rhus succedanea extracts for ruminants. Asian Australas. J. Anim. Sci. 2018, 31, 1635-1642. [CrossRef] [PubMed]

31. Yu, Z.; Morrison, M. Improved extraction of PCR-quality community DNA from digesta and fecal samples. Biotechniques 2004, 36, 808-812. [CrossRef] [PubMed]

32. Denman, S.E.; McSweeney, C.S. Development of a real-time PCR assay for monitoring anaerobic fungal and cellulolytic bacterial populations within the rumen. FEMS Microbiol. Ecol. 2006, 58, 572-582. [CrossRef]

33. Sylvester, J.T.; Karnati, S.K.; Yu, Z.; Morrison, M.; Firkins, J.L. Development of an assay to quantify rumen ciliate protozoal biomass in cows using real-time PCR. J. Nutr. 2004, 134, 3378-3384. [CrossRef]

34. Rong-Fu, W.; Wei-Wen, C.; Cerniglia, C.E. PCR detection of Ruminococcus spp. in human and animal faecal samples. Mol. Cell. Probes 1997, 11, 259-265.

35. Stevenson, D.M.; Weimer, P.J. Dominance of Prevotella and low abundance of classical ruminal bacterial species in the bovine rumen revealed by relative quantification real-time PCR. Appl. Microbiol. Biotechnol. 2007, 75, 165-174. [CrossRef]

36. Paillard, D.; McKain, N.; Chaudhary, L.C.; Walker, N.D.; Pizette, F.; Koppova, I.; McEwan, N.R.; Kopecný, J.; Vercoe, P.E.; Louis, P.; et al. Relation between phylogenetic position, lipid metabolism and butyrate production by different Butyrivibrio-like bacteria from the rumen. Antonie Van Leeuwenhoek 2007, 91, 417-422. [CrossRef]

37. Tajima, K.; Aminov, R.I.; Nagamine, T.; Matsui, H.; Nakamura, M.; Benno, Y. Diet-dependent shifts in the bacterial population of the rumen revealed with real-time PCR. Appl. Environ. Microbiol. 2016, 7, 2766-2774. [CrossRef] [PubMed]

38. Whelan, J.A.; Russell, N.B.; Whelan, M.A. A method for the absolute quantification of cDNA using real-time PCR. J. Immunol. Methods 2003, 278, 261-269. [CrossRef]

39. SAS Institute Inc. SAS/STAT User's Guide: Version 9.2; SAS Institute Inc.: Cary, NC, USA, 2002.

40. Lee, O.H.; Lee, B.Y. Antioxidant and antimicrobial activities of individual and combined phenolics in Olea europaea leaf extract. Bioresour. Technol. 2010, 101, 3751-3754. [CrossRef] [PubMed]

41. Brahmi, F.; Flamini, G.; Issaoui, M.; Dhibi, M.; Dabbou, S.; Mastouri, M.; Hammamoi, M. Chemical composition and biological activities of volatile fractions from three Tunisian cultivars of olive leaves. Med. Chem. Res. 2012, 21, 2863-2872. [CrossRef]

42. Hatice, Z.; Ayse, H.B. Antibacterial and antioxidant activity of essential oil terpenes against pathogenic and spoilage-forming bacteria and cell structure-activity relationships evaluated by SEM microscopy. Molecules 2014, 19, 17773-17798.

43. Sudjana, A.N.; d'Orazio, C.; Ryan, V.; Rasool, N.; Ng, J.; Islam, N.; Riley, T.V.; Hammer, K.A. Antimicrobial activity of commercial Olea europaea (olive) leaf extract. Int. J. Antimicrob. Agents 2009, 33, 461-463. [CrossRef]

44. Techathuvanan, C.; Reyes, F.; David, J.R.; Davidson, P.M. Efficacy of commercial natural antimicrobials alone and in combinations against pathogenic and spoilage microorganisms. J. Food Prot. 2014, 77, 269-275. [CrossRef]

45. Mothana, R.A.; Lindequist, U. Antimicrobial activity of some medicinal plants of the island Soqotra. J. Ethnopharmacol. 2005, 96, 177-181. [CrossRef]

46. Benchaar, C.; McAllister, T.A.; Chouinard, P.Y. Digestion, ruminal fermentation, ciliate protozoal populations, and milk production from dairy cows fed cinnamaldehyde, quebracho condensed tannin, or yucca schidigera saponin extracts. J. Dairy Sci. 2008, 91, 4765-4777. [CrossRef]

47. Lee, O.H.; Lee, H.B.; Son, J.Y. Antimicrobial activities and nitrite-scavenging ability of olive leaf fractions. Korean J. Soc. Food Cook. Sci. 2004, 20, 86-92.

48. Davis, W.W.; Stout, T.R. Disc plate method of microbiological antibiotic assay: I. Factors influencing variability and error. Appl. Microbiol. 1971, 22, 659-665. [CrossRef]

49. Lee-Huang, S.; Zhang, L.; Huang, P.L.; Chang, Y.T.; Huang, P.L. Anti-HIV activity of olive leaf extract (OLE) and modulation of host cell gene expression by HIV-1 infection and OLE treatment. Biochem. Biophys. Res. Commun. Actions 2003, 307, $1029-1037$. [CrossRef]

50. Eom, J.S.; Lee, S.J.; Lee, Y.; Kim, H.S.; Choi, Y.Y.; Kim, H.S.; Kim, D.H.; Lee, S.S. Effects of supplementation levels of Allium fistulosum L. extract on in vitro ruminal fermentation characteristics and methane emisson. Peer J. 2020, 8, e9651. [CrossRef] [PubMed]

51. Ernesto Vargas, J.; Andrés, S.; López-Ferreras, L.; Snelling, T.J.; Yáñez-Ruíz, D.R.; García-Estrada, C.; López, S. Dietary supplemental plant oils reduce methanogenesis from anaerobic microbial fermentation in the rumen. Sci. Rep. 2020, 10, 1613. [CrossRef] [PubMed]

52. Tapio, I.; Snelling, T.J.; Strozzi, F.; Wallace, R.J. The ruminal microbiome associated with methane emissions from ruminant livestock. J. Anim. Sci. Biotechnol. 2017, 8, 7. [CrossRef]

53. Denis, O.K.; Stuart, E.D.; Roderick, I.M.; Mark, M.; Ann, L.R.; Graeme, T.A.; Christopher, S.M. Opportunities to improve fiber degradation in the rumen: Microbiology, ecology, and genomics. FEMS Microbiol. Rev. 2003, 27, 663-693. 